\section{Branch retinal vein occlusion treated by intravitreal triamcinolone acetonide}

\author{
Abstract \\ Purpose To evaluate the effect of intravitreal \\ triamcinolone acetonide on visual acuity in \\ branch retinal vein occlusion. \\ Methods The prospective comparative \\ nonrandomized clinical interventional study \\ included 28 patients ( 28 eyes) with branch \\ retinal vein occlusion. The study group \\ consisting of 10 consecutive patients received \\ an intravitreal injection of $20-25 \mathrm{mg}$ of \\ triamcinolone acetonide. The control group \\ including 18 patients did not receive an \\ intravitreal injection. The mean follow-up was \\ $8.7 \pm 4.4$ months. \\ Results In the study group, mean visual \\ acuity increased significantly $(P=0.02)$ from \\ $0.27 \pm 0.11$ preoperatively to a best \\ postoperative visual acuity of $0.45 \pm 0.27$. \\ Visual acuity measurements determined 1 \\ month after the injection were significantly \\ $(P=0.027)$ higher than baseline values. Nine \\ $(90 \%)$ eyes gained in visual acuity, with six \\ $(60 \%)$ eyes showing an increase in visual \\ acuity of at least two Snellen lines. In the \\ ischaemic subgroup, visual acuity did not \\ change significantly $(0.18 \pm 0.18$ to $0.13 \pm 0.04$; \\ $P=0.66)$, while, in the nonischaemic \\ subgroup, visual acuity increased significantly \\ $(P=0.012)$ from the baseline value to the best \\ postoperative measurement $(0.29 \pm 0.09$ to \\ $0.53 \pm 0.24)$. In the control group, baseline \\ visual acuity and best visual acuity during the \\ follow-up did not vary significantly $(P=0.27)$. \\ Comparing the study and control groups with \\ each other, the gain in visual acuity was \\ significantly higher in the study group at 1 \\ month $(P=0.016)$ and 2 months $(P=0.012)$ \\ after baseline. \\ Conclusions Intravitreal injection of \\ triamcinolone acetonide can increase visual \\ acuity in patients with branch retinal vein \\ occlusion.
}

JB Jonas, I Akkoyun, B Kamppeter, I Kreissig and RF Degenring

Eye (2005) 19, 65-71. doi:10.1038/sj.eye.6701395

Published online 23 April 2004

Keywords: branch retinal vein occlusion; triamcinolone acetonide; intraocular steroids; intravitreal steroids; intraocular pressure; cystoid macular oedema

\section{Introduction}

Intravitreal triamcinolone acetonide has increasingly been used in previous studies for treatment of intraocular proliferative, oedematous, and neovascular diseases, such as diffuse diabetic macular oedema, ${ }^{1-3}$ proliferative diabetic retinopathy, ${ }^{4}$ neovascular glaucoma, ${ }^{5}$ central retinal vein occlusion, ${ }^{6-8}$ proliferative vitreoretinopathy, ${ }^{9}$ chronic pre-phthisical ocular hypotony, ${ }^{10}$ chronic uveitis, ${ }^{11-15}$ persistent pseudophakic cystoid macular oedema, ${ }^{16-18}$ exudative age-related macular degeneration, ${ }^{19-25}$ cystoid macular oedema due to retinitis pigmentosa, ${ }^{26}$ ischaemic ophthalmopathy, ${ }^{27}$ sympathetic ophthalmia, ${ }^{28}$ idiopathic juxtafoveal telangiectasis, ${ }^{29}$ as visualization aid during pars plana vitrectomy, ${ }^{30}$ and in other clinical situations. ${ }^{31-36}$ In aqueous humour and in silicone oil, respectively, triamcinolone acetonide has been found up to 1.5 years and up to 8 months, respectively, after the intravitreal injection. ${ }^{37-40}$ Systemic and local side effects reported so far include cataract, secondary ocular hypertension, leading in some patients to secondary chronic open-angle glaucoma, ${ }^{41-43}$ and postinjection infectious endophthalmitis. ${ }^{44-46}$

Due to its antioedematous and antiangiogenic effects as shown in experimental investigations and clinical studies, ${ }^{4-51}$ intravitreal triamcinolone acetonide has additionally been used in previous pilot studies on central retinal vein occlusions. It was the purpose of the
Department of

Ophthalmology and Eye Hospital

Faculty for Clinical Medicine Mannheim Ruprecht-KarlsUniversity Heidelberg Germany

Correspondence: J Jonas, MD

Universitäts-Augenklinik Theodor-Kutzer-Ufer 1-3 Mannheim 68167 Germany

Tel: + 49-621-383-2652

Fax: + 49-621-383-3803

E-mail: Jost.Jonas@ augen.ma.uni-heidelberg.de Proprietary interest: none.

Received: 1 October 2003 Accepted: 10 November 2003

Published online: 23 April 2004 
present study to evaluate whether intravitreal triamcinolone acetonide may be therapeutically useful to increase visual acuity in patients with long-standing cystoid macular oedema due to branch retinal vein occlusion.

\section{Methods}

The prospective comparative nonrandomized clinical interventional study included all 10 patients (five women; 10 eyes; six right eyes), who consecutively presented with branch retinal vein occlusion, who received an intravitreal injection of $20-25 \mathrm{mg}$ of triamcinolone acetonide, who did not undergo cataract surgery in combination with, or after, the intravitreal injection, and for whom follow-up was 1 month or longer (Table 1). All patients were fully informed about the experimental character of the therapy. All patients signed an informed consent. The study was performed at a university hospital. The ethics committee of the university had approved the study following the tenets of the Declaration of Helsinki. The mean age of the patients was $73.9 \pm 7.3$ years, mean refractive error was $1.01 \pm 1.70 \mathrm{D}$ (Table 1 ). Mean follow-up time was $8.7 \pm 4.4$ months. Fluorescein angiogram performed for all patients showed a marked cystoid macular oedema, in addition to intraretinal haemorrhages in the region of the branch retinal vein occlusion. Two eyes (20\%) showed the ischaemic type of branch retinal vein occlusion, and the remaining eight $(80 \%)$ eyes showed the nonischaemic type of branch retinal vein occlusion.

The study group was compared with a control group including 18 eyes (nine right eyes) of 18 patients (10 women), who did not receive an intravitreal injection of triamcinolone acetonide. In four $(22 \%)$ eyes, a retinal argon laser coagulation was performed as treatment of branch retinal vein occlusion during the follow-up. Five (28\%) patients of the control group showed the ischaemic type of branch retinal vein occlusion, and 13 (72\%) showed the nonischaemic type. Due to the distribution of patients into the study group and the control group, both groups did not vary significantly in preoperative visual acuity $(P=0.27)$, preoperative intraocular pressure $(P=0.19)$, age $(P=0.11)$, refractive error $(P=0.46)$, gender $(P=1.01)$, right or left eye $(P=0.71)$, follow-up time $(P=0.13)$, and ischaemic $v$ nonischaemic type of branch retinal vein occlusion $(P=1.0)$ (Table 1$)$.

All patients complained about a loss of vision experienced at least 5 months prior to the intravitreal injection. The mean visual acuity at baseline of the study was $0.27 \pm 0.11$ (median 0.25 ; range $0.05-0.50$ ) in the study group, and it was $0.35 \pm 0.16$ (median 0.40 ; range 0.06-0.50) in the control group. The mean intraocular pressure measured $16.9 \pm 3.2 \mathrm{mmHg}$ for the patients of the study group, and it was $15.2 \pm 2.9 \mathrm{mmHg}$ for the patients of the control group (Table 1).

At baseline of the study and in repeated intervals afterwards, all patients underwent a routine ophthalmologic examination including standardized visual acuity measurement using Snellen charts, slitlamp biomicroscopy, Goldmann applanation tonometry, and ophthalmoscopy. For the patients of the study group, the examinations were routinely performed during the first week after the injection, and roughly in monthly intervals after the injection. For all patients included in the study, the results of at least one examination performed at least 1 month, or later, after the intravitreal injection were available.

The intravitreal injection of triamcinolone acetonide was performed under sterile conditions in the operation theatre, using an operation microscope. Prior to the intravitreal injection, topical Betadine $\mathrm{R}^{\mathrm{R}}$ (povidone-iodine $5 \%$ ) (Alcon, Ft Worth, TX, USA) was applied, and after that the patients were completely draped. A lid speculum was inserted and a paracentesis carried out to decrease the volume of the eye. The injection of $20-25 \mathrm{mg}$ $(0.2 \mathrm{ml})$ crystalline triamcinolone acetonide was performed through a sharp 27-gauge needle through the inferior pars plana, at 3-3.5 mm from the limbus. After that, an antibiotic ointment (polymyxin and neomycine) was applied. The triamcinolone acetonide had been prepared by extracting $0.625 \mathrm{ml}$ from the ampoule (Volon

Table 1 Composition of the study population and visual acuity prior to the intravitreal injection of 20-25 mg triamcinolone acetonide

\begin{tabular}{lccc}
\hline & Study group & Control group & P-value \\
\hline$n$ & 10 & 18 & 0.11 (NS) \\
Age & $73.9 \pm 7.3$ & $66.1 \pm 9.8$ & 0.46 (NS) \\
Refract. error & $1.01 \pm 1.70$ & $1.45 \pm 2.19$ & 0.13 (NS) \\
Range & -1.50 to +3.75 & -2.63 to +7.00 & $5.8 \pm 5.0$ \\
Follow-up period & $8.7 \pm 4.4$ & 4.0 & $1.3-18.2$ \\
Median & 9.4 & $15.2 \pm 2.9$ & 0.19 (NS) \\
Range & $1.4-13.6$ & $16.9 \pm 3.2$ & \\
Intraocular pressure $(\mathrm{mmHg})$ &
\end{tabular}

$P$-value: significance of difference between preoperative visual acuity and postoperative visual acuity in each study group. 
$\mathrm{A}^{\mathrm{R}}$, Bristol-Myers-Squibb, Germany) containing $40 \mathrm{mg}$ of triamcinolone acetonide in $1 \mathrm{ml}$. The extracted volume was filled into a tuberculin syringe $(1 \mathrm{ml})$ or a $2 \mathrm{ml}$ syringe. The syringe was filled up with Ringer's solution. A millipore filter (pore size, $5 \mu \mathrm{m}$ ) was placed on top of the syringe, and most of the content of the syringe was pressed through the filter, with the triamcinolone acetonide crystals remaining in the syringe. The syringe was re-filled with Ringer's solution, and the same procedure was repeated for three times. At the end, $0.2 \mathrm{ml}$ of solution in the syringe was left, and, using a 27gauge needle, the content was injected transconjunctivally into the vitreous cavity.

Statistical analyses were performed by using a commercially available statistical software package (SPSS for Windows, version 11.5, SPSS, Chicago, IL, USA). To test the statistical significance of differences between the study group and the control group, the Mann-Whitney test, Wilcoxon-test, or Student's-t-test for parameters such as intraocular pressure and visual acuity were used. For parameters such as gender and right or left eye, the $\chi^{2}$ test was applied. The level of significance was 0.05 (two-sided) in all statistical testing.

\section{Results}

In the study group, mean visual acuity increased from 0 . $27 \pm 0.11$ preoperatively to a best visual acuity during the follow-up of $0.45 \pm 0.27$ (Table 2; Figure 1). The difference between the baseline value and the best postoperative value was statistically significant $(P=0.02)$. Nine (90\%) eyes showed at least one visual acuity measurement better during the follow-up compared with baseline of the study. Measured in Snellen lines, six (60\%) eyes showed an improvement by at least two Snellen lines or more. Visual acuity measurements determined 1 month

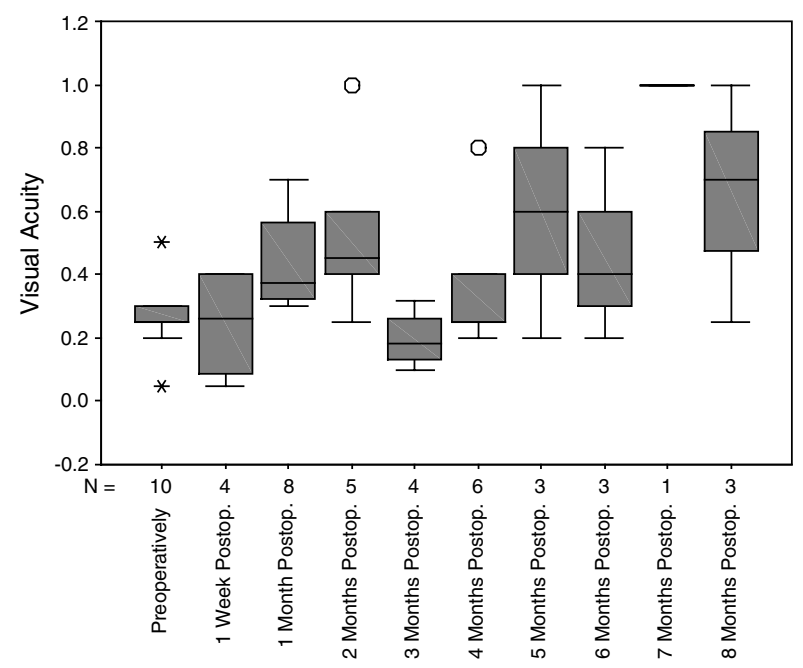

Figure 1 Boxplots showing visual acuity (VA) prior to, and after, the intravitreal injection of $20-25 \mathrm{mg}$ of triamcinolone acetonide in eyes with branch retinal vein occlusion.

after the injection were significantly $(P=0.027)$ higher than the baseline values (Table 2). There was no clear tendency of visual acuity measurements to return to the baseline values at the end of the follow-up (Table 2;

Figure 1). Considering visual acuity measurements taken at the end of the follow-up, visual acuity measurements were higher, however not significantly higher, than the values obtained at the baseline of the study.

The difference to the baseline visual acuity was not significant $(P=0.59)$ (Table 2$)$.

Dividing the study group into the ischaemic subgroup $(n=2)$ and the nonischaemic group $(n=8)$ revealed that preoperative visual acuity was lower, however not statistically lower $(P=0.71)$, in the ischaemic subgroup $v s$ the nonischaemic subgroup $(0.18 \pm 0.18$ vs $0.29 \pm 0.09)$. In the ischaemic subgroup, visual acuity did not change significantly $(0.18 \pm 0.18$ to $0.13 \pm 0.04 ; P=0.66)$, while,

Table 2 Visual acuity in the study group

\begin{tabular}{lcrrr}
\hline & Visual acuity & P-Value & Gain in visual acuity & Snellen lines \\
\hline $\begin{array}{l}\text { Preoperatively } \\
\text { Postinjection }\end{array}$ & $0.27 \pm 0.11(n=10)$ & & & \\
1 week & $0.24 \pm 0.18(n=4)$ & 0.72 (NS) & $-0.02 \pm 0.21$ & $-1.75 \pm 4.86$ \\
1 month & $0.44 \pm 0.15(n=8)$ & 0.027 & $0.15 \pm 0.15$ & $2.30 \pm 1.86$ \\
2 months & $0.54 \pm 0.29(n=5)$ & 0.14 (NS) & $0.25 \pm 0.20$ & $2.50 \pm 2.08$ \\
3 months & $0.20 \pm 0.09(n=4)$ & 1.0 (NS) & $-0.02 \pm 0.10$ & $0.00 \pm 2.58$ \\
4 months & $0.36 \pm 0.23(n=6)$ & 0.47 (NS) & $0.11 \pm 0.25$ & $1.00 \pm 2.68$ \\
5 months & $0.60 \pm 0.40(n=3)$ & 0.47 (NS) & $0.28 \pm 0.29$ & $2.33 \pm 3.06$ \\
6 months & $0.47 \pm 0.31(n=3)$ & 0.47 (NS) & 0.50 & $0.67 \pm 1.53$ \\
7 months & $1.00(n=1)$ & - & $0.33 \pm 0.29$ & 3.0 \\
8 months & $0.65 \pm 0.38(n=3)$ & 0.28 (NS) & $0.19 \pm 0.22$ & $2.83 \pm 2.75$ \\
Best postop. vis. acuity & $0.45 \pm 0.27(n=10)$ & 0.02 & $0.05 \pm 0.19$ & $1.89 \pm 2.26$ \\
Vis. acuity at study end & $0.31 \pm 0.27(n=10)$ & 0.59 (NS) & & $-0.05 \pm 2.57$ \\
\hline
\end{tabular}

$P$-value: significance of difference to the baseline visual acuity. 
Table 3 Visual acuity in the control group

\begin{tabular}{|c|c|c|c|c|}
\hline & Visual acuity & P-value & Gain in visual acuity & Snellen lines \\
\hline Preoperatively & $0.35 \pm 0.16(n=18)$ & & & \\
\hline \multicolumn{5}{|l|}{ Post injection } \\
\hline 1 month & $0.32 \pm 0.13(n=4)$ & 0.08 (NS) & $-0.15 \pm 0.10$ & $-1.75 \pm 1.26$ \\
\hline 2 months & $0.26 \pm 0.17(n=8)$ & 0.04 & $-0.09 \pm 0.13$ & $-1.71 \pm 2.56$ \\
\hline 3 months & $0.53 \pm 0.32(n=4)$ & 0.11 (NS) & $0.20 \pm 0.18$ & $1.75 \pm 1.26$ \\
\hline 4 months & $0.28 \pm 0.21(n=4)$ & 0.72 (NS) & $0.05 \pm 0.17$ & $1.67 \pm 2.52$ \\
\hline 5 months & $0.60 \pm 0.08(n=4)$ & 0.10 (NS) & $0.10 \pm 0.08$ & $0.88 \pm 0.63$ \\
\hline 6 months & $0.18 \pm 0.18(n=2)$ & 0.66 (NS) & $0.02 \pm 0.31$ & $0.00 \pm 9.99$ \\
\hline 8 months & $0.31 \pm 0.27(n=2)$ & 0.32 (NS) & $0.03 \pm 0.05$ & $1.50 \pm 2.12$ \\
\hline Best postop. vis. acuity & $0.40 \pm 0.24(n=18)$ & 0.27 (NS) & $0.05 \pm 0.21$ & $0.25 \pm 3.34$ \\
\hline Vis. acuity at study end & $0.36 \pm 0.26(n=18)$ & 0.89 (NS) & $0.01 \pm 0.24$ & $-0.81 \pm 3.96$ \\
\hline
\end{tabular}

$P$-value: significance of difference to the baseline visual acuity.

in the nonischaemic subgroup, visual acuity increased significantly $(P=0.012)$ from the baseline value to the best postoperative measurement $(0.29 \pm 0.09$ to $0.53 \pm$ 0.24). Expressed in Snellen lines, the postoperative increase in visual acuity was higher, however not significantly $(P=0.71)$ higher, in the nonischaemic subgroup than in the nonischaemic subgroup $(2.3 \pm 1.7$ Snellen lines vs $0.0 \pm 4.2$ Snellen lines).

In the control group, baseline visual acuity and best visual acuity during the follow-up did not vary significantly $(0.35 \pm 0.16$ vs $0.40 \pm 0.24 ; P=0.27)$ (Table 3). Visual acuity at the end of the follow-up did not differ significantly $(P=0.89)$ from the baseline values (Table 3). Eight eyes (44\%) showed at least one visual acuity measurement better during the follow-up compared with baseline of the study. For seven (39\%) eyes, visual acuity measurements after baseline of the study were worser than those at the start of the study.

Comparing the study and control groups with each other, gain in visual acuity measured 1 month after baseline of the study was significantly higher in the study group than in the control group $(2.30 \pm 1.86$ Snellen lines $v s-1.75 \pm 1.26 ; P=0.016)$. The same hold true for visual acuity measurements obtained at 2 months after the start of the study $(P=0.012)$. For visual acuity measurements performed later during the followup, the number of patients may have been too small for a statistical analysis (Tables 2, 3). Maximal gain in visual acuity was higher, however not significantly $(P=0.12)$ higher, in the study group (1.89 \pm 2.26 Snellen lines) than in the control group $(0.25 \pm 3.34$ Snellen lines). The number of eyes demonstrating an improvement in visual acuity during the follow-up was higher, however not statistically significantly $(P=0.065)$, in the study group than in the control group.

In the study group, intraocular pressure increased significantly $(P=0.007)$ from $16.9 \pm 3.2 \mathrm{mmHg}$ (median $17 \mathrm{mmHg}$; range $12-23 \mathrm{mmHg}$ ) at baseline of the study to a mean maximal value of $23.5 \pm 4.4 \mathrm{mmHg}$ (median
$23 \mathrm{mmHg}$; range $18-32 \mathrm{mmHg}$ ), and decreased significantly $(P=0.03)$ again to $19.8 \pm 6.2 \mathrm{mmHg}$ (median $17 \mathrm{mmHg}$; range $15-32 \mathrm{mmHg}$ ) at the end of the follow-up. The preoperative intraocular pressure measurements and the pressure readings at the end of the follow-up period did not differ significantly $(P=0.27)$. During the study period, intraocular pressure was higher than $21 \mathrm{mmHg}$ in seven $(70 \%)$ eyes. In all of these eyes, intraocular pressure could be normalized by topical antiglaucomatous medication. Glaucomatous damage of the optic nerve as determined by biomorphometry of the optic nerve head ${ }^{12}$ was not detected.

In the control group, intraocular pressure at baseline of the study $(15.2 \pm 2.9 \mathrm{mmHg})$, intraocular pressure measurements during the follow-up (peak: $14.8 \pm$ $4.1 \mathrm{mmHg}$ ), and at the end of the study did not vary significantly $(P>0.20)$. None of the eyes of the control group developed intraocular pressure measurements higher than $23 \mathrm{mmHg}$ during the follow-up.

Correspondingly, intraocular pressure during the followup $(P<0.001)$ and at the end of the study $(P=0.002)$ was significantly higher in the study group than in the control group. Both groups did not vary significantly $(P=0.19)$ in intraocular pressure at baseline of the study (Table 1).

In none of the patients, triamcinolone acetonide crystals had settled on the macular region. The crystals were preretinally located in the vitreous cortex at the 6 o'clock position and did not optically interfere with vision. In none of the eyes included in the study, postoperative infectious endophthalmitis, sterile endophthalmitis, rhegmatogenous retinal detachment or proliferative vitreoretinopathy were observed.

\section{Discussion}

The results of the study suggest that intravitreal triamcinolone acetonide may be useful to increase visual acuity in patients with branch retinal vein occlusion. The 
patients of the study group experienced a significant increase in visual acuity, while the patients of the control group did not show a significant change in visual acuity during the follow-up (Tables 2, 3; Figure 1). Comparing the study and control groups with each other, gain in visual acuity was significantly more marked in the study group for the measurements obtained 1 and 2 months after baseline. It confirms previous studies in which intravitreal triamcinolone acetonide reduced macular oedema in eyes with different diseases such as pseudophakic cystoid macular oedema, uveitis, exudative age-related macular degeneration, and diffuse diabetic macular oedema. ${ }^{1-3,6-8,11-26,29}$ The present study on branch retinal vein occlusion is in agreement also with studies on patients with retinal vein occlusions in which intravitreal triamcinolone acetonide led to a marked decrease in macular oedema, and to a slight increase in visual acuity. ${ }^{6-8}$

Previous studies on central retinal vein occlusion and exudative age-related macular degeneration demonstrated an increase in visual acuity or a relative decrease in the size of the subfoveal neovascularization membrane in the first few months after an intravitreal injection of triamcinolone, and they showed a re-decline in visual acuity about 3-5 months after the injection. . $^{6,19-25}$ In contrast to the latter studies, the present investigation did not show a clear tendency of a decrease in visual acuity towards the end of the study. It may suggest that, in eyes with branch retinal vein occlusion, intravitreal triamcinolone acetonide may be associated with a longer lasting increase in visual acuity compared with eyes with central retinal vein occlusion and exudative age-related macular degeneration.

The reasons why intravitreal steroids increase vision in patients with macular oedema have been elusive; however, stabilization of the blood-retinal barrier may play a significant part. ${ }^{48,52}$ One of the reasons why visual acuity did not increase more than that found in the present study may be macular ischaemia and tissue destruction accompanying retinal vein occlusions. It is reflected in the finding that, in the ischaemic subgroup of the study group, visual acuity did not change significantly $(P=0.66)$ after the intravitreal injection, while, in the nonischaemic subgroup, visual acuity increased significantly $(P=0.012)$. If retinal cells have been lost due to capillary nonperfusion, or if intraretinal intercellular structures have been disrupted due to chronic macular oedema and swelling, resolution of the oedema may only have a limited effect in raising visual function.

Direct toxic effects of triamcinolone acetonide on the retina and optic nerve were not observed in the present study nor in other studies on eyes in which the same dosage of triamcinolone acetonide was injected for various reasons. . $^{1,5,7,9,10,18,23,24,27,28,32-38,40,42}$

Correspondingly, a recent safety and efficacy study of an intravitreal fluocinolone acetonide sustained delivery device as treatment for cystoid macular oedema in patients with uveitis ${ }^{13}$ and other clinical and experimental studies have not shown a toxic effect of intraocular steroids. ${ }^{53-56}$ An elevation of intraocular pressure above $21 \mathrm{mmHg}$ occurring in seven eyes (70\%) in the present study was not a major clinical problem. In all these eyes, intraocular pressure could be controlled by topical antiglaucomatous treatment. Similar observations were made by Wingate ${ }^{41}$ and colleagues, Martidis ${ }^{2}$ and colleagues, and Bakri and Beer ${ }^{43}$ using a dosage of $4 \mathrm{mg}$ of triamcinolone acetonide, as well as in other previous studies using a dosage of $20-25 \mathrm{mg}$ of triamcinolone acetonide. $^{42}$

A major difference between the studies on the intravitreal application of triamcinolone acetonide performed by others and the present investigation is the dosage of triamcinolone intravitreally injected. In all previous studies on intravitreal applications of triamcinolone acetonide for cystoid macular oedema, diabetic macular oedema, and macular degeneration performed by other researchers, dosages of $4 \mathrm{mg}$ or less of triamcinolone acetonide were used. The reasons why we used a dosage of $20-25 \mathrm{mg}$ of triamcinolone acetonide instead of a dosage of $4 \mathrm{mg}$ have been that, right from the beginning of the ongoing triamcinolone studies now involving more than 500 patients, we have used the same dosage of 20-25 mg of triamcinolone acetonide, and that we have not seen side effects so far that may be attributed to that high dosage. It also holds true for repeated intravitreal injections of $20-25 \mathrm{mg}$ of triamcinolone acetonide. ${ }^{23,25}$

The most important limitation of the present study is that it is not a randomized prospective investigation in which the patients were randomly distributed between a study group and a control group. Yet, nine (90\%) eyes gained in visual acuity after the injection of triamcinolone acetonide, with six $(60 \%)$ eyes gaining in visual acuity by at least two Snellen lines. Furthermore, one has to consider that the effect of a triamcinoloneinduced cataract formation on visual acuity has not been taken into account in the assessment of visual acuity in the present study. The cataract-associated decrease in visual acuity may have compensated or partially covered an increase in visual acuity due to the effect of triamcinolone acetonide. Other limitations of the study are the relatively small number of patients included in the study group, and the relatively short follow-up period.

In conclusion, the patients included in the present study showed after an intravitreal injection of $20-25 \mathrm{mg}$ of triamcinolone acetonide a significant increase in visual 
acuity. Side effects of the intravitreal injection of triamcinolone acetonide were an elevation in intraocular pressure in seven (70\%) eyes, and, probably, an increase in cataract formation. A steroid-induced rise in intraocular pressure could medically be controlled. In agreement with previous case reports on the effect of intravitreal triamcinolone acetonide on macular oedema due to retinal vein occlusions, ${ }^{6-8,57}$ the results of the present study on branch retinal vein occlusion suggest that the intravitreal injection of triamcinolone acetonide may be a therapeutic option to temporarily increase visual acuity in patients with branch retinal vein occlusions.

\section{References}

1 Jonas JB, Söfker A. Intraocular injection of crystalline cortisone as adjunctive treatment of diabetic macular oedema. Am J Ophthalmol 2001; 132: 425-427.

2 Martidis A, Duker JS, Greenberg PB, Rogers AH, Puliafito $\mathrm{CA}$, Reichel $\mathrm{E}$ et al. Intravitreal triamcinolone for refractory diabetic macular oedema. Ophthalmology 2002; 109: 920-927.

3 Jonas JB, Kreissig I, Söfker A, Degenring RF. Intravitreal injection of triamcinolone acetonide for diabetic macular oedema. Arch Ophthalmol 2003; 121: 57-61.

4 Jonas JB, Hayler JK, Söfker A, Panda-Jonas S. Intravitreal injection of crystalline cortisone as adjunctive treatment of proliferative diabetic retinopathy. Am J Ophthalmol 2001; 131: 468-471.

5 Jonas JB, Hayler JK, Söfker A, Panda-Jonas S. Regression of neovascular iris vessels by intravitreal injection of crystalline cortisone. J Glaucoma 2001; 10: 284-287.

6 Greenberg PB, Martidis A, Rogers AH, Duker JS, Reichel E. Intravitreal triamcinolone acetonide for macular oedema due to central retinal vein occlusion. Br J Ophthalmol 2002; 86: $247-248$.

7 Jonas JB, Kreissig I, Degenring RF. Intravitreal triamcinolone acetonide as treatment of macular oedema in central retinal vein occlusion. Graef Arch Clin Exp Ophthalmol 2002; 240: 782-783.

8 Park $\mathrm{CH}$, Jaffe GJ, Fekrat S. Intravitreal triamcinolone acetonide in eyes with cystoid macular edema associated with central retinal veinocclusion. Am J Ophthalmol 2003; 136: 419-425.

9 Jonas JB, Hayler JK, Panda-Jonas S. Intravitreal injection of crystalline cortisone as adjunctive treatment of proliferative vitreoretinopathy. Br J Ophthalmol 2000; 84: 1064-1067.

10 Jonas JB, Hayler JK, Panda-Jonas S. Intravitreal injection of crystalline cortisone as treatment of pre-phthisical ocular hypotony. Graef Arch Clin Exp Ophthalmol 2001; 239: 464-465.

11 Antcliff RJ, Spalton DJ, Stanford MR, Graham EM, ffytche TJ, Marshall J. Intravitreal triamcinolone for uveitic cystoid macular oedema: an optical coherence tomography study. Ophthalmology 2001; 108: 765-772.

12 Martidis A, Duker JS, Puliafito CA. Intravitreal triamcinolone for refractory cystoid macular oedema secondary to birdshot retinochoroidopathy. Arch Ophthalmol 2001; 119: 1380-1383.

13 Young S, Larkin G, Branley M, Lightman S. Safety and efficacy of intravitreal triamcinolone for cystoid macular oedema in uveitis. Clin Exp Ophthalmol 2001; 29: 2-6.
14 Degenring RF, Jonas JB. Intravitreal injection of triamcinolone acetonide as treatment of chronic uveitis. $\mathrm{Br} \mathrm{J}$ Ophthalmol 2003; 87: 361.

15 Sonoda KH, Enaida H, Ueno A, Nakamura T, Kawano YI, Kubota $\mathrm{T}$ et al. Pars plana vitrectomy assisted by triamcinolone acetonide for refractory uveitis: a case series study. Br J Ophthalmol 2003; 87: 1010-1014.

16 Benhamou N, Massin P, Haouchine B, Audren F, Tadayoni $\mathrm{R}$, Gaudric A. Intravitreal triamcinolone for refractory pseudophakic macular oedema. Am J Ophthalmol 2003; 135: 246-249.

17 Conway MD, Canakis C, Livir-Rallatos C, Peyman GA. Intravitreal triamcinolone acetonide for refractory chronic pseudophakic cystoid macular oedema. J Cataract Refract Surg 2003; 29: 27-33.

18 Jonas JB, Kreissig I, Degenring RF. Intravitreal triamcinolone acetonide for pseudophakic cystoid macular oedema. Am J Ophthalmol 2003; 136: 384-386.

19 Penfold P, Gyory J, Hunyor A, Billson FA. Exudative macular degeneration and intravitreal triamcinolone. A pilot study. Aust NZ J Ophthalmol 1995; 23: 293-298.

20 Danis RP, Ciulla TA, Pratt LM, Anliker W. Intravitreal triamcinolone acetonide in exudative age-related macular degeneration. Retina 2000; 20: 244-250.

21 Gillies MC, Simpson JM, Luo W, Penfold P, Hunyor AB, Chua $\mathrm{W}$ et al. A randomized clinical trial of a single dose of intravitreal triamcinolone acetonide for neovascular agerelated macular degeneration: one-year results. Arch Ophthalmol 2003; 121: 667-673.

22 Spaide RF, Sorenson J, Maranan L. Combined photodynamic therapy with verteporfin and intravitreal triamcinolone acetonide for choroidal neovascularization. Ophthalmology 2003; 110: 1517-1525.

23 Jonas JB, Kreissig I, Degenring RF. Repeated intravitreal injections of triamcinolone acetonide as treatment of progressive exudative age-related macular degeneration. Brief Report. Graef Arch Clin Exp Ophthalmol 2002; 240: 872-873.

24 Jonas JB, Kreissig I, Hugger P, Sauder G, Panda-Jonas S, Degenring R. Intravitreal triamcinolone acetonide for exudative age-related macular degeneration. $\mathrm{Br} \mathrm{J}$ Ophthalmol 2003; 87: 462-468.

25 Jonas JB, Akkoyun I, Budde WM, Kreissig I, Degenring RF. Intravitreal re-injection of triamcinolone for exudative agerelated macular degeneration. Arch Ophthalmol 2004, (in print).

26 Saraiva VS, Sallum JM, Farah ME. Treatment of cystoid macular edema related to retinitis pigmentosa with intravitreal triamcinolone acetonide. Ophthalmic Surg Lasers Imaging 2003; 34: 398-400.

27 Jonas JB, Kreissig I, Degenring RF. Intravitreal triamcinolone as treatment for ischaemic ophthalmopathy. Eur J Ophthalmol 2003; 13: 575-576.

28 Jonas JB. Intravitreal triamcinolone acetonide for treatment of sympathetic ophthalmia. Am J Ophthalmol 2004, (in print).

29 Alldredge CD, Garretson BR. Intravitreal triamcinolone for the treatment of idiopathic juxtafoveal telangiectasis. Retina 2003; 23: 113-116.

30 Peyman GA, Cheema R, Conway MD, Fang T. Triamcinolone acetonide as an aid to visualization of the vitreous and the posterior hyaloid during pars plana vitrectomy. Retina 2000; 20: 554-555.

31 Rechtman E, Allen VD, Danis RP, Pratt LM, Harris A, Speicher MA. Intravitreal triamcinolone for choroidal 
neovascularization in ocular histoplasmosis syndrome. Am J Ophthalmol 2003; 136: 739-741.

32 Scott IU, Flynn HW, Rosenfeld PJ. Intravitreal triamcinolone acetonide for idiopathic cystoid macular edema. Am J Ophthalmol 2003; 136: 737-739.

33 Jonas JB, Kreissig I, Degenring RF. Cataract surgery after intravitreal injection of triamcinolone acetonide. Eye 2004, (in print).

34 Jonas JB. Intravitreal triamcinolone acetonide as treatment of chronic focal immunologic corneal graft reaction. Brief Report. Graef Arch Clin Exp Ophthalmol 2003; 241: 779-780.

35 Jonas JB. Intravitreal triamcinolone acetonide as treatment for extensive exudative retinal detachment? $\mathrm{Br} J$ Ophthalmol 2004, (in print).

36 Jonas JB, Kreissig I, Degenring RF. Neovascular glaucoma treated by intravitreal triamcinolone acetonide. Acta Ophthalmol 2003; 81: 540-541.

37 Jonas JB. Concentration of intravitreally applicated triamcinolone acetonide in aqueous humour. $\mathrm{Br} \mathrm{J}$ Ophthalmol 2002; 86: 1066.

38 Jonas JB. Concentration of intravitreally injected triamcinolone acetonide in intraocular silicone oil. $\mathrm{Br} \mathrm{J}$ Ophthalmol 2002; 86: 1450-1451.

39 Beer PM, Bakri SJ, Singh RJ, Liu W, Peters III GB, Miller M. Intraocular concentration and pharmacokinetics of triamcinolone acetonide after a single intravitreal injection. Ophthalmology 2003; 110: 681-686.

40 Jonas JB. Intraocular availability of triamcinolone acetonide after intravitreal injection. Am J Ophthalmol 2004, (in print).

41 Wingate RJ, Beaumont PE. Intravitreal triamcinolone and elevated intraocular pressure. Aust N Z J Ophthalmol 1999; 27: 431-432.

42 Jonas JB, Kreissig I, Degenring R. Intraocular pressure after intravitreal injection of triamcinolone acetonide. $\mathrm{Br} \mathrm{J}$ Ophthalmol 2003; 87: 24-27.

43 Bakri SJ, Beer PM. The effect of intravitreal triamcinolone acetonide on intraocular pressure. Ophthalmic Surg Lasers Imaging 2003; 34: 386-390.

44 Benz MS, Murray TG, Dubovy SR, Katz RS, Eifrig CW. Endophthalmitis caused by Mycobacterium chelonae abscessus after intravitreal injection of triamcinolone. Arch Ophthalmol 2003; 121: 271-273.

45 Jonas JB, Kreissig I, Degenring RF. Endophthalmitis after intravitreal injection of triamcinolone acetonide. Arch Ophthalmol 2003; 121: 1663-1664.
46 Jonas JB, Bleyl U. Morphallaxia-like ocular histology after intravitreal triamcinolone acetonide. Br J Ophthalmol 2004, (in print).

47 Ishibashi T, Miki K, Sorgente N, Patterson R, Ryan SJ. Effects of intravitreal administration of steroids on experimental subretinal neovascularization in the subhuman primate. Arch Ophthalmol 1985; 103: 708-711.

48 Wilson CA, Berkowitz BA, Sato Y, Ando N, Handa JT, de Juan Jr E. Treatment with intravitreal steroid reduces bloodretinal barrier breakdown due to retinal photocoagulation. Arch Ophthalmol 1992; 110: 1155-1159.

49 Antoszyk AN, Gottlieb JL, Machemer R, Hatchell DL. The effects of intravitreal triamcinolone acetonide on experimental pre-retinal neovascularization. Graefes Arch Clin Exp Ophthalmol 1993; 231: 34-40.

50 Penfold PL, Wen L, Madigan MC, King NJ, Provis JM. Modulation of permeability and adhesion molecule expression by human choroidal endothelial cells. Invest Ophthalmol Vis Sci 2002; 43: 3125-3130.

51 Penfold PL, Wong JG, Gyory J, Billson FA. Effects of triamcinolone acetonide on microglial morphology and quantitative expression of MHC-II in exudative age-related macular degeneration. Clin Exp Ophthalmol 2001; 29: 188-192.

52 Penfold PL, Wen L, Madigan MC, Gillies MC, King NJ, Provis JM. Modulation of permeability and adhesion molecule expression by human choroidal endothelial cells. Invest Ophthalmol Vis Sci 2002; 43: 3125-3130.

53 McCuen II BW, Bessler M, Tano Y, Chandler D, Machemer $\mathrm{R}$. The lack of toxicity of intravitreally administered triamcinolone acetonide. Am J Ophthalmol 1981; 91: 785-788.

54 Hida T, Chandler D, Arena JE, Machemer R. Experimental and clinical observations of the intraocular toxicity of commercial corticosteroid preparations. Am J Ophthalmol 1986; 101: 190-195.

55 Kwak HW, D'Amico DJ. Evaluation of the retinal toxicity and pharmacokinetics of dexamethasone after intravitreal injection. Arch Ophthalmol 1992; 110: 259-266.

56 Kivilcim M, Peyman GA, El-Dessouky ES, Kazi AA, Cheema R, Hegazy H. Retinal toxicity of triamcinolone acetonide in silicone-filled eyes. Ophthalmic Surg Lasers 2000; 31: 474-478.

57 Degenring RF, Kamppeter B, Kreissig I, Jonas JB. Morphologic and functional changes after intravitreal triamcinolone acetonide for retinal vein occlusion. Acta Ophthalmol 2003; 81: 548-550. 